\title{
LITTLE MAGAZINES IN INDIA AND EMERGENCE OF DALIT LITERATURE
}

\author{
Dr. Preeti Oza \\ St. Andrew's College \\ Mumbai University \\ Preetioza1@gmail.com
}

INTRODUCTION

As encyclopaedia Britannica defines: -Little Magazine is any of various small, usually avant-garde periodicals devoted to serious literary writings. || The name signifies most of all a usually non-commercial manner of editing, managing, and financing. They were published from 1880 through much of the 20th century and flourished in the U.S. and England, though French and German writers also benefited from them.

\section{HISTORY}

Literary magazines or _small magazines' are traced back in the UK since the 1800 s. Americas had North American Review (founded in 1803) and the Yale Review(1819). In the 20th century: Poetry Magazine, published in Chicago from 1912, has grown to be one

of the world's most well-regarded journals. The number of small magazines rapidly increased when the independent Printing Press originated in the mid $20^{\text {th }}$ century. Small magazines also encouraged substantial literary influence. It provided a very good space for the marginalised, the new and the uncommon. And that finally became the agenda of all small magazines, no matter where in the world they are published: To promote literature - in a broad, all- encompassing sense of the word - through poetry, short fiction, essays, book reviews,

literary criticism and biographical profiles and interviews of authors. Little magazines heralded a change in literary sensibility and in the politics of literary taste. They also promoted alternative perspectives to politics, culture, and society.

In India, the beginning of Little Magazine is found in the early $20^{\text {th }}$ century when many marginal content writers have started voicing their ideas in these non-commercial, non- main stream journals and magazines. The regional and vernacular writers found a new medium in these periodicals. Dalit writings, especially Dalit poetry has gained a lot of momentum via these small magazines which were highly regional in nature; both the language and the circulation.

Dalit literature is a literature of revolt and enigma, protest and negativism. The social, economic and cultural inequality faced by _Untouchables' finally made them start and join many movements. The protest against establishment of the Dalits gained the very first expression amidst the Dalit literature. In the midst of the cobweb of poems, fiction, novels and autobiographies the age-old questions of Dalit identity was addressed. These movements have a long history and which also is spreads into many verticals of parallel protests. The Dalit literary movement in India is significant not only from the literary perspective but it has changed the whole spectrum of socio-political writings in many parts of India. It has provided a new avenue of liberation for Dalits.

Caste system, =Verna _system, untouchability and social discrimination have subjugated a very large part of our society. Dr. Ambedkar named it _Dalit' and Indian Constitution called it _Scheduled Caste', but this marginalised group has existed consistently in our history of time. Shudra, Atishudra, Pancham, Avarna, Ashprushya, Chandal, Antyaj, Dhedh, Bhangi, Harijan, Dalit, Dippressed class, Bahujan... are some of the identities given to them with little pride and more of insult. So the need of any literature or journalism which gives voice to these people is very clear.

\section{THE BEGINNING}

Dalit literary movement began in Maharashtra, the birthplace of Dr. Babasaheb Ambedkar. Many small scale Marathi literary journals have supported this movement. According to the Encyclopaedic Dictionary of Marathi Literature, -The focus of these magazines is their insistence on locating contemporary Marathi poetry in the context of the tremendous social changes that have taken place due to 


\section{GAP INTERDISCIPLINARITIES -}

globalisation and the policies of the Indian Government like liberalisation and privatisation.|| For example, on the cover page of

his first magazine $=$ Mook Nayak‘ on $31^{\text {st }}$ January 1920, Dr. Ambedkar has put these lines of Tukaram's Abhanga:

-kaykaruaatandharuniabheed, Nishank hai taund vaajvile

Navhe jagi koni mukkikat yanchya jaan Sarthak lajun nahve heet.

(Why should I keep quiet now? I have been anyways speaking openly. There is no place for a mute in this world. Nothing is gained by keeping quiet)

Historically, = Mook Nayak' (1920) is considered a first attempt in Marathi dalit magazine. But before that = Dinbandhu' started by Jyotibaa Phule (1877) was a starting point. Phule disciple Gopal Buva Walangkar started_Vitaal Widhwansak' in 1888. In 1908 _Somvanshiya Mitra' was started by Shankar Prasadik who was working for the removal of untouchbility. It was continued till June 1910, almost 23 months. In 1907 $=$ Bahishkrut Bharat' was started by

= Dippressed Classes Mission Society'. Dr. Ambedkar has mentioned some contemporary magazines like =Dinmitra', 'Jagruk', 'Deccan', 'Reyat', 'Gyan Prakash' and_Subodh' in his

=Mook nayak'. Dr. Ambedkar had managed some of these magazines in his wide spread public life;

1. Mook Nayak-1920-1923

2. Bahishkrut Bharat-1927-1929 3. Samta-1928-1929

4. Janta-1930-1956

5. Prabuddh Bharat-1956-1958.

Though all these magazine don't come under the category of _Little magazine', they have contributed significantly in establishing dalit writing is Marathi and other languages.

The Dalit Literary movement has gained momentum in $1960 \mathrm{~s}$ and $70 \mathrm{~s}$, and The Little Magazine movement has contributed largely in reaching out to the masses with the short stories, comparative articles and burning poems. The _Dalit' has got a new face of _Angry Young Man' in the pages of these little magazines. These magazines provided a spatial social thought process which helped some of the protest literatures to get established as a mainstream study.

In 1940, Bal Sitaram Mardhekar was the most prominent name. He influenced many small non-periodical magazines in next thirty years. In India, the small magazine gained strength in the culturally rich atmosphere of the $1950 \mathrm{~s}$ and $60 \mathrm{~s}$ in a movement to publish literature in regional languages. Shabda was published by Dilip Chitre, Arun Kolatkar and ramesh Samarth.

- Vacha and Aso published writings of radical and angry young writers like Namdeo Dhasal, Vasant Dhake, Vasant Gurjar, Vilas Sarang and Manohar Oak.

- Arun Kolatkar, Ashok Shahane and Dilip Chitre started the earliest and most influential little magazine in Marathi_Shabda' (1954-1960)

- Bal Sitaram Mardhekar brought modernism in Marathi Poetry through Abhiruchi- a little magazine in 1946.

- From 1955 to 1975 avant grade poetics found its expression in little magazines like

- $\quad$ Shabda', 'Vacha' and literary periodicals like_Asmitadarsh'.

The movement started full-heartedly in Marathi literature in the period 1955-1975. The era was dominated by the little magazine movement where writers Dilip Chitre, Arun Kolatkar published cyclostyled Shabda. In the early 1960s the movement took the revolutionary writers by storm, ushering in modernish and the Dalit movement.

Writers like Baburao Bagul, and Shankarrao Kharat emerged because of The Little Magazine Movement which has provided an angry and an accusative face to the literature. It became more questioning with the passing time and Dalit Literature gained momentum as a strong voice. The Marathi little magazine movement lost momentum in the 1970s and 1980s, but a resurgence in the 1990s saw the founding of journals Abhidhanantar, Sausthav and Shabdavedh.

The Little Magazine Movement in Marashtra saw a new high under the writings of Baburao Bagul, Madhav Bandhu and Shankarrao Kharat. Bagul's writings included collection of short stories Jenvah Mee Jaat Chorli Hoti' (when I robbed a caste), conventional story writing in Marathi _Sood" (Revenge), his novels Aghori and Kondi - the exemplifying stories of misery. Bagul was the first writer to associate Dalit 
literature with African - American literature(s). This initiation was the beginning of the internationalisation of Dalit literature.

It was only a decade after Shabda -- the poetry magazine launched in 1954-55 and ceased to publish in 1960 -- that the movement gathered momentum. With only a limited number of pages per issue, they could publish mostly poetry, critical commentary, and short pieces of fiction. In the 60s the flow of the Dalit literary writing increased in the form of short stories novels and dramas in 70s individual volumes of poetry began to pour in and published by the Maharashtra Buddhist literature committee, Asmitadarsh press or the Marxist magova press.

A prominent group of other writers like Arun Kamble, Krishna Kamble, Raja Dhale, Laxman Mane, Hari Narake, Sharankumar Limbale, Waman Nibalkar, Bhimsen Dethe continued to write according to vision of their own, all of them speaking about the inner quest for identity. Namdeo Dhasal, Arun Kamble and Raja Dhale formed _Dalit Panther Movement' as a social organization. NamdeoDhasal's poetry opened with an unprecedented outburst of creative activity among Dalits. Dhasal's first collection of poems in Golpitha' took Marathi literary circles by storm and broke all the rules of traditional Marathi literature. The use of language was shocking to the traditionalists.

Mumbai being the financial capital of India witnessed an overwhelming force against liberalization, privatization and globalization in 1990s. The technology had affected deeply the embryonic Indian digital age group. The dramatic changes had forced idealistic writers to raise their voice against blind technological boom that affected greatly Indian society and culture. Abhidhantar, Shabdavedk, Suashtav, Aivaji, Khel, Anaghrat and Navakshar Darshan surfaced in this period. Poets like Manya Joshi, Mangesh Naryanrao Kale, Hemant Divate, Sanjeev Khandekar, Saleel Wagh and Sachin Ketkar burst upon the scene with sensible writings unlike the revolutionary 60 s writers.

The Little Magazine movement has been quite prominent in the Hindi heartland, in Bengal, in Kerala, and in Maharashtra. -The Little Magazine movement was always about resisting the establishment. The politics was always around the caste, class analysis, around people who are never represented,\| says Satish Kaleskar, a poet and writer from Raigad, Maharashtra. He has seen the movement evolve from the 1960 's to the present day. Several of his poems have been translated into other languages. He has participated in the Little Magazines movement in Marathi: he has edited and published Fakta,Tapasi, Chakravarti, Vacha, and now Vangmay-Vrutta.

-In the 1960's the movement was about getting the under-represented classes to become a part of the literary scene. Thanks to the years of intervention, the Marathi Sahitya Sammelan has seen many dalit presidents. From Naryana Surve to Keshav Meshram to Uttam Kamble to FM Shinde in 2014, we have had presidents of the Sammelan who are from backward castes,\| says Kaleskar. The Little Magazine movement in Marathi began around 1960. Till this time, the established Marathi literature was generally focused towards purely aesthetic discussion. The year 1960 marks a stage when the post-Independence generation appeared on the literary scene, especially the Dalits and the working class people whose voice was rarely heard till then. This new generation of writers was naturally isolated from the mainstream and though the writers connected with it were keen to project their viewpoints, they lacked the infrastructure of a big publishing house, an effective distribution network that the mainstream writers have recourse to.

As Arun Kolatkar echoes Ezra Pound's thoughts: - Nothing written for pay is worth printing; only what is written against market||. This love for context, nunance and the offbeat might not be in step with the hysteria of the mass media cycle obsessed with personalities, horse races and opinion polls. But the little magazine provides a different perspective, whether its about the arts of politics.

Abhidhanantar, a quarterly edited by Hemant Divate, was one of the foremost little magazines in Marathi. It saw uninterrupted publication for almost a decade and half. It was one of the earliest literary magazines and a literary movement in Marathi to recognize and respond creatively to the powerful forces of globalization which were rapidly transforming Indian society, culture and life. Abhidhanantar gave generous attention to the linguistic, cultural and literary changes taking place, as well as to the crises they led to, in the post- 1990s.

\section{INFLUENCE ON OTHER LANGUAGES DALIT WRITINGS:}

Gujarati writings got influenced by the dalit movement and showed an emergence of Little magazine movement in first two decades of $20^{\text {th }}$ century. Nav Yuvak' (1930) was the first magazine to help and support Antyaj bandhu'. Some of the issues discussed in it were an invite to dalit youngsters to come ahead and unite, a report on the Round table Conference and Dr. Ambedkar's lecture in it, Kalaram Temple entry and critic of gandhiji and Arya samaj activities.

The little magazines of that era can also be divide in two major parts: inspired by Gandhi Ideology and inspired by Ambedkar ideology.

In 1931 _Dalit Unnati' started as a mouth piece of _Ashprusyata Nivaran sangh', though the editors were non-dalits. 1932 saw the emergence of _Vijay' which was known as _Harijans' magazine'. Its editor Madhav 
parmar had also started „mangal Prabhat' in 1949. _Antyaj Patrika' was a magazine supported by nonDalits.

Ambedkar influenced some of the dalit magazines like ${ }_{\equiv} B$ Bherubandh'( 1939). It started with the main objectives like - to remove untouchability, rebel against Hindus and to spread awareness in dalits.

A weekly named _Challenge' started in 1946 from Mumbai by Advocate Hirji patel. Its cover page carried _jai Bheem' and jai Fedration'. Though it could not survive for more than a year, it has contributed a lot in spreading dalit_Chetana'.

A magazine called Jai Bheem' was the supported by All India Scheduled caste federation. Though it cannot be called a little Magazine, it was major dalit magazine. Post 1960 in Gujarat saw an array of small time magazines dealing with issues related to Dalits.

- Garud: (1971-78). Dalpat Srimali, who was earlier a Gandhian activist, has started Garud . he was vocally critical about the double standards and hypocrisy of some of the Gandhians. Garud provided a platform for new writers writing about injustice to Dalits or issues of untouchability and provided a voice to a large number of voice-less people.

- Dalit Bandhu: Started in 1973 and continued for a longer time than other contemporaries. It had a special_Dalit Kavita Corner‘

- _Taras': started in 1943 in Mumbai, it is a publication of a specific caste ( Mahyavanshi) but it has published many articles, short stories, essays and travelogues.

- _Akrosh': started in 1978, it published the works of Neerav patel, Dalpat chauhan, Pravin gadhvi and Yogesh Dave.during 1981 Gujarat riots, it has creted lots of buzz with its radical writings.

- _Kalo Suraj': first published in 1979, it is also known as the mouth piece of dalit poetry. Some prominent writers who wrote in it are Dr. Pinakin Dave, Mohammad Sheikh, Dr. Mafat Oza and Joseph Macwan.

- _Panther': Started in 1975, it was a publication of _Dalit Panther-Gujarat'. Panther leaders like Ramesh Parmar and Nagin Parmar were editors. Some of the important writes like Neeraj Patel, jayprakash Dolas, Angat Chauhan, and Raja Jadav had contributed in its success.

Disha: Since last 25 years, this is the only magazine still continuing with Dalit writings. Many translations of Marathi Dalit literature, poems of Mangal rathod and B.V.Vankar and articles of N.V.Chavda are some of the highlights of this magazine.

Some other important magazines in this category are = Lagam', _Parishd sandesh' _Samaj Mitra', Avasar',_Kahani',_Mukti nayak' and _Prabudhdha Bharat'.

\section{REFERENCES}

Aston, N.M. Ed.Dalit literature and African-American literature. Prestige Books, New Delhi. 2001.

Baburao, Bagul, _Dalit Sahitya: Man greatness, man's freedom‘ Asmitadarsh Vol.I, 1973.

Dangle, Arjun; Poisoned Bread editor, Orient Longman Limited 1992

Dhananjaykeer, Dr.Ambedkar: Life and Mission, Popular Prakashan, Bombay.

Dhasal, Namdeo Poet of the Underworld: Poems 1972-2006, Navayana (translated by Dilip Chitre)

Early Dalit Literature and Culture in Late Nineteenth- and Early Twentieth-Century Western India, Philip Constable,

Limbale, Sharankumar Towards and Aesthetics of Dalit Literature in English Orient Longman (translated by Alok Mukherje) 2004,

Mishra, Jugal Kishore A Critical study of Dalit Literature in India. Swedish South Asian

Modern Asian Studies, Modern Asian Studies / Volume 31 / Issue 02 / May 1997

Natarajan, Nalini ed.A Handbook of Twentieth-Century Literatures of India. Greenwood Press: Westport, CT. 1996. 